\title{
Which Indonesian Small and Medium Firms Use Formal Financial Services?
}

\author{
Raymond J. Struyk \\ NORC at the University of Chicago \\ 4350 East-West Highway, Suite 800, Bethesda, MD 20814 \\ Tel: 1-301-634-9434Ｅ-mail: Struyk-Ray@norc.org \\ Samuel R. Haddaway \\ NORC at the University of Chicago \\ 4350 East-West Highway, Suite 800, Bethesda, MD 20814 \\ Tel: 1-301-634-9423 E-mail: Haddaway-Sam@norc.org
}

Received: February 3, 2011

Accepted: March 5, 2011

doi:10.5539/ijef.v3n4p3

The data used in this analysis was gathered under an IFC-Jakarta contract with NORC (contract 7151518). The authors especially thank Kabul Sarwoto, who directed the surveys for Yayasan Inovasi Pemerintahan Daerah (YIPD).YRoger Thomas Moyes, Neil Philip Ramsden, and Nyoman Gde Satrya Wibawa at the IFC office were particularly helpful. Views expressed are those of the authors and not the above listed organizations.

\begin{abstract}
Data from a survey on the utilization of financial services of small and medium size Indonesian firms is used to identify the firm characteristics associated with accessing financial services from formal (regulated) sources. Three decisions are analyzed: choosing to use a service, choosing the service provider, and choosing the delivery channel. Models are estimated for eight choices: five for a financial service selection (loan, ATM card, saving account, checking account, transfer services); one for a provider choice (commercial bank versus other providers for loans), and two for a channel choice (ATM versus visiting a bank branch for accessing savings accounts, and visiting a branch versus other options for making transfers). Our choices were constrained by many options having very low utilization rates and therefore not being good candidates for logit estimation. The results show the importance of relationship banking for accessing loans. Growing firms, as indicated by increasing revenue in the last year, are consistently associated with the utilization of products and channels, such as ATMs, that would save time by reducing trips to the bank branch.
\end{abstract}

Keywords: SME finance, Developing countries, Financial products, Southeast Asia

\section{Introduction}

In Indonesia's economy, as in many other developing nations, micro, small, and medium enterprises (SMEs) play a dominant role. The national statistics office estimates that in 2006 they constituted 99 percent of all businesses in the country, employed 97 percent of the work force, and accounted for 54 percent of GDP. The focus of this analysis is on the comparatively small share of firms in the small-medium group (16.4 percent together). These firms often have the potential for sustained growth. Their potential for growth is evident because they have already cleared the formidable hurdle of transitioning from micro to small firm size. However, they are struggling in Indonesia: according to Asia Foundation analysis "this middle sector failed to develop as it should because government policies favored large enterprises while creating, via high regulatory hurdles, incentives for firms to remain small" (Asian Foundation (2005), p. 40; Note 1).

SMEs in Indonesia and elsewhere consistently report problems in obtaining access to credit. Finance shortages are more problematic among small and medium firms than micro firms in Indonesia because of ready lending sources for small loans to micro firms (Godau, Hiemann, and Jansen, 2004, pp. 2-3). On the other hand, contemporary pressures are pushing commercial banks to extend credit to smaller firms. One reason is the tough competition and margin erosion in the corporate market. Banks have responded to this by competing to serve the strongest "medium size" firms. But margins here have also sharply tightened, creating pressure to move further down the size spectrum. 
Although access to credit is the traditional vantage point from which much of the SME literature views financial services, it is more appropriate to take into account the full array of banking services, including deposit accounts, insurance, and transactions services. These additional services can improve SMEs' efficiency in conducting a wide array of transactions and managing their liquidity, permitting owner-managers to spend more time on the shop floor; in short, they can raise the return on investment.

Banks seeking to expand revenues through SME operations want to sell as many products to SMEs as they can. Therefore, this article's perspective is to address questions about SMEs' access to a wide range of products. We analyze small-medium firm characteristics associated with several decisions about financial services:

- Deciding to use financial services, including deposit accounts, loans, and transactions

- Deciding to take a loan from a commercial bank rather than another source (This is commercial banks versus "others" because no other single course alone accounts for a meaningful share of the loan market.)

- For major financial services, deciding on the delivery channel, e.g., obtaining cash from an ATM or bank branch.

In other words, we follow three decisions: product choice, vendor choice, and delivery channel choice. Understanding the systematic variance in SMEs' choices should be of significant interest to banks because it can improve their ability to target marketing activities and increase revenue in an increasingly competitive market.

In addition to descriptive information on these points, the innovative analysis presented is the results of estimated regression (logit) models of decision determinants. To date, few such estimates have been published. (One exception is Bebczuk's (2004) model estimates for access to credit in Argentina.) This information should be highly valuable to financial services providers.

The primary data is from an in-depth survey of a representative sample of 602 small-medium firms in large Indonesian cities (over 250,000 population) in summer 2009. Also employed are results of a survey done at the same time of 20 commercial banks and other formal financial institutions (plus 3 informal lenders, ("loan sharks"), that gathered information on the volume of SME deposit products, type of liability and transactional products offered to SMEs, loan volumes, loan terms, and delivery channels and initiatives being undertaken to reach the small-medium firm market (Note 2).

The paper is organized as follows. The next section provides a brief review of prior studies on financial services used by small-medium firms in Indonesia and a review the international literature on SME use of ATM services in developing countries. The third section presents basic information on the use of financial services by small-medium Indonesian firms. The fourth section presents the logit models and their results. The final section offers some conclusions.

\section{Use of Formal Finance Services}

\subsection{International Perspective}

Several cross-country studies employing firm level data have documented that, compared to larger firms, SMEs perceive the lack of access to finance and the cost of loans to be greater obstacles to development and high profits. They also show that finance shortages restrict development of small firms more than large firms (Beck and Demirguc-Kunt, 2006; Beck et al., 2006). Schiffer and Weder (2001) show the same broad pattern using observations on over 10,000 firms in 80 countries. Simple differences in the mean ratings of the problem of restricted availability of finance (rated 1-to-4) are highly significant, with small firms having the highest deficit. But when they use ordered-probit analysis of firms' ratings of financial access severity, the result is no longer significant when the age of the firm and some equity participation by the government or foreign firms is controlled. These findings point to an unmet demand for finance. That said, information on the specific loan products and financial services preferred by SMEs is scarce and there is little research reported on the specific situation of small and medium firms.

In contrast to the research on the firm side, there has been little analysis of the supply side of the market across countries. Recent analysis by Beck et al. (2008) uses data for 91 banks from 45 countries, both developed and developing, to document banks' lending practices to SMEs and their attitudes toward such lending. The authors reach three conclusions of particular relevance here: (1) banks perceive SME lending as very profitable, (2) banks are less exposed to small firms than large firms, and (3) banks charge small firms higher interest rates, fees, and experience higher loan delinquency rates (Beck et al. 2008, pp.2-3).

A second relevant study explores the effect of competition among financial institutions on the availability of finance for SMEs (Beck et al., 2004). The study employs data from 74 developed and developing countries, including firm-level ratings of problems in obtaining finance (Note 3). The figures show that Indonesia is about average in 
terms of finance being reported by firms as an obstacle to firm development.

These data are important because the analysis shows that a greater degree of banking concentration lowers the relative access of firms to credit, especially smaller firms. Greater problems in the regulatory area and certain institutional characteristics are also associated with firms citing a higher level of credit obstacles, but the effect diminishes in countries with higher GDP levels. In short, some attributes of the Indonesian banking system in 2001 were broadly working against access to finance, according to these findings.

The literature on the use of ATMs in developing countries often assesses ATMs as one e-channel, along with PCs and kiosks. Much of the published literature focuses on first-world countries, and articles for developing and transition countries mostly addresses consumer use rather than SME utilization. (See Gao and Owolabi, 2008, Hwang et al., 2007).

Two consistent findings are that (1) service reliability and interface performance are prime determinants of consumer acceptance (Casalo at al., 2008), and (2) the availability of ATM services outside of bank branch office working hours is a major advantage (Gerrard and Cunningham, 2003). Moreover, one e-channel cannot be viewed in isolation. The e-channel suite must function consistently well together (Hway-Boon and Yu (2003); Ong and Chen (2003); and, Patricio et al., (2003).)

A study of 221 SMEs in Lahore explored reasons why e-banking was used by such firms. The SME sample was drawn from the Yellow Pages and respondents had to be computer literate-conditions that make it a rather restricted sample. But the results are still interesting. Sixty-five percent of respondents had never accessed their bank's website for financial purposes, and, of these, 54 percent reported using the website daily. The top four reasons for using e-banking were: convenience, saving time, facilitating making quick responses, and minimization of the risk of carrying cash (Kaleem and Ahmed, 2009). Overall, the study shows that firms selecting internet banking services use them fairly intensively and for readily understood reasons.

\section{Situation in Indonesia}

Some studies of the Indonesian SME sector have relevant findings on the need for finance. In general, Indonesian studies document significantly restricted access to loans. (See, for example, Subdani, (2007), Rafinaldy, (2004), and Deputi Bidang Pengkajian (2006).) Most relevant for this paper is a Development Alternatives Incorporated (DAI) study completed in 2004 that focused on small and medium firms in East Java. The survey found that 19 percent of small-medium firms rated finance as a "principal problem" and another 16 percent rated it as a secondary problem. While substantial, these are in a distant second place behind "market problems," i.e., insufficient demand or too much competition, which half of all respondents as a primary or secondary problem.

The same survey inquired about wider banking services. Eighty-one percent reported having a savings or deposit account, 58 percent reported using a bank to send or receive funds, and 57 percent reported using an ATM card. The incidence of business loans was only 34 percent. Respondents were also asked to identify the "most helpful" banking services. The top four services were: a savings or deposit account (rated most helpful by 30 percent of respondents), an ATM card (24 percent), sending and receiving transfers (21 percent), and business loans (12 percent). The priority of non credit services is striking. As documented below, these utilization patterns are similar to those found in the survey employed here.

On the supply side, a 2005 Bank Indonesia study reported that banks were motivated to expand their lending to SMEs by the profitability of the activity. A series of actions were cited that banks were undertaking to expand their lending. Keys to successful expansion included stronger underwriting, streamlining the lending process, and rigorous collections systems (Bank Indonesia, 2005). These findings are highly consistent with those of the bank survey done as part of the present study, presented in Struyk 2010a.

Today, banks are extending a substantial volume of credit to SMEs. Indeed, under central bank directives about half of commercial bank loans went to micro, small and medium firms in the last quarter of 2008. At the same time, the SME loan volume was divided such that 35 percent went to micro, 34 percent to small, and 31 percent to medium size firms - a surprisingly flat distribution, especially considering that micro firms substantially outnumber big ones. But compared to the number of firms loan volume is very unevenly distributed. The "loan intensity index" (the ratio of the percent of bank loans to the firm group to the percent of firms in the group) ranges from 0.5 for micro firms to over 50 for medium firms. So loan volume per 1 percent of medium firms is 100 times the loan volume per 1 percent of micro firms and much higher on a per firm basis.

\section{Financial Service Utilization}

This section presents basic information on the three topics listed in the introduction: small and medium firms' use of various financial services, their selection of the type of institutions that provide them, and their selection of 
distribution channels. Data are from the small-and-medium firm survey cited above. All data are population estimates based on the application of weights to sample firms (Struyk et al., 2009).

Regarding the use of services from all sources, clear penetration patterns are evident:

- Three services dominate: a savings or deposit account (used by 88 percent of firms), ATM cards (60 percent), and sending or receiving transfers (28 percent).

- Only two other services are used by more than 10 percent of firms: demand accounts and business loans (both 13 percent).

- Six other services are each used by only 3 to 7 percent of firms: credit cards, personal loans, factoring, telephone banking, internet banking, and bank payroll services.

- The remaining three services are used by less than one percent of firms: international transfers, letters of credit, and leasing.

The fact that business loans are only tied for $4^{\text {th }}$ place in the incidence-of-use rankings is striking given the attention this service receives. The remainder of the discussion and analysis focuses on the "Big 5" financial services.

Table 1 presents for each of the Big 5 services its percentage distribution across formal (supervised) service providers and then across delivery channels. The balance of the article focuses on the utilization of services from formal sources.

The second panel shows that commercial banks are the overwhelming provideer for 4 of the 5 , all except business loans. One reason is that non bank financial institutions (cooperatives and multifinance companies) are not permitted to take deposits or are restricted in the type they can take. So they do not offer ATM and transfer services. Another reason is that commercial banks have much larger branch office and ATM networks than the rural, regional development banks, or banks offering only Sharia-compliant products (labeled "Sharia banks" in the table).

For business loans, commercial banks still dominate with 69 percent of the clients. Cooperative banks are the second largest supplier (23 percent) and Sharia banks are third (6 percent).

ATM card holders report two primary reasons for having ATM cards: the transaction process is smooth and simple (54 percent) and using cards is cheaper than using other transaction means (32 percent). Satisfaction with the card services is very high. Major reasons driving the satisfaction (respondents could give multiple responses) are: security of the transaction (45 percent), ease of the transaction (32 percent), and breadth of the distribution system (31 percent).

The final panel of the table shows the delivery channels used for the Big 5 services. As one would expect, the dominant channel for two products are essentially tautological: ATM cards are used almost exclusively at ATM machines; and, checking accounts are used by 95 percent of firms at branch offices, although they could be accessed through ATMs.

The story is similar for business loans: 95 percent applied for at branch offices and another 3 percent are done through phone banking. Survey results show that the most frequent "principal reason" for selecting a particular institution for a loan was past experience with that lender (39 percent of firms). A related principal reason was having other accounts at the institution (19 percent). This kind of loyalty indicates the payoff to good services and cross selling.

\section{Quantitative Analysis}

This section begins by listing the dependent variables for the model estimated. It then outlines our hypotheses about how firm characteristics influence the choice of financial services, provider type, and distribution channel. Results of the estimated logit models are then presented and interpreted.

We have estimated eight models - five for financial service selection, one for provider choice, and two for channel choice. Logit model estimation is less reliable when the share of one choice is much under 10 percent of the sample; so our choices were constrained by many options having very low utilization rates. The models are estimated with unweighted data, and the distribution of choices is materially changed from those presented in Table 1 by this adjustment, as shown by the dependent variable values in the lower part of Table 4 .

The dependent variables are defined in Table 2 and are grouped by the three decisions. In the service choice models, the dependent variable indicates whether the firm uses the service from any formal source. The provider choice model examines loan sources: the dependent variable indicates whether the loan is taken from a commercial bank or from some other source (Note 4).

In the two delivery channel models, the dependent variable indicates the delivery channel. For the model using 
transfers, the variable shows whether a transfer was made though a branch teller or through some other source. For the model using savings accounts, the variable shows whether the savings account was accessed through an ATM or through a bank branch.

The shift to unweighted data made it impractical to limit some analyses to two loan sources or two delivery channels. Despite the small share of firms using ATMs to access savings accounts as opposed to bank branches (.04), we nevertheless estimated this model on an experimental basis. The alternative of using all non-branch teller access methods has a mean of only .06 and the results of the estimated model were less interesting.

Several hypotheses were formulated about how firms' characteristics would influence the choice decision; these are summarized in Table 3. While many are self-explanatory, commentary on some is warranted.

Firm size, measured here by the number of employees, is anticipated to result in a higher likelihood of service usage. Bigger firms receive greater attention and respect at bank branches. Determined cross selling at the branch should encourage use of additional services. Moreover, larger firms' managers tend to be exposed to information on both services and distribution channels, making them more likely to try new options. It is also probable that as size increases firms will use relatively less of some services, e.g., less use of ATMs for cash payments to staff and suppliers.

Survey data show that women owner/managers use certain services less often than men (Struyk et al., 2010a). For example, they less often have property insurance (sold by some major banks) than men (13 vs. 5 percent). They are also less likely to use the computer and internet in their business (18 for men vs. 8 percent for women). These points suggest that women are less likely to access some services or use different delivery channels. On the other hand, if they feel discriminated against when visiting bank branches, they could prefer the impersonal ATM machines for their transactions provided that they feel safe using them.

A survey of banks and the 'mystery shopping' exercise undertaken as part of the larger project produced substantial evidence that banks and NBFIs are primarily asset-based lenders rather than cash-flow or project-lenders (Struyk et al., 2010a). Collateral often in excess of 100 percent of loan principal is required, while information about the expected cash flow of investments made with loan proceeds is seldom used in the loan underwriting process (Struyk et al., 2010a). Our measure of assets, however, is gross assets and not the more relevant measure of assets net of encumbrances.

Lastly, relationship banking is reputed to be very important in Indonesia and developing countries generally. Once a firm has established a working relationship with a bank branch, it is more efficient to return to the same branch for services. As the branch staff becomes more familiar with the owner and his experience in paying loans and otherwise using services, they are more likely to offer further services, assuming the experience is positive. For this reason we expect that firms with their accounts concentrated at a bank have a greater likelihood of accessing the various services and of taking their loan from a commercial bank rather than another source that the provider choice logit model. The effect of relationship banking on delivery channel use is less clear. The owner may visit the branch to keep up his relationship even though use of an ATM would be more efficient.

We acknowledge that these models are not fully specified. The most important omission is the price of the service and delivery channel alternatives offered by different financial institutions. Another important omission is the density of service provision, i.e., the number of ATMs and branch offices in a city. This can be thought of as a price component - the cost of accessing a service, which is in addition to the provider's service fee.

Table 4 presents the estimated models. For ease of interpretation, the entries in the body of the table are effect on the probability of using the service or channel assessed at the mean of the dependent variable. (The probability $=b * P i$ * (1-Pi), where Pi is the mean value of the dependent variable and $b$ is the regression coefficient.) The entry shows the effect of a unit change in the independent variable.

\subsection{Choice to Use a Service}

The first five models are for the "Big 5" services, and we first examine loans. In this model, two variables have powerful effects on the probability of taking a loan from a formal source: whether the firm obtained a loan from a formal financial institution during start-up and the extent to which it has concentrated its accounts with a single bank. Start-up finance increases the probability by 16 percent; an SME with two accounts at a single institution is 18 percent more likely to take a loan from a formal source that with one account at a single institution. Both of these results speak to relationship banking and indicate that banks that can establish firms as clients for savings or checking accounts are in a strong position to sell them loans. Contrary to expectations, greater assets do not play a role; this may be due to the use of gross rather than unencumbered assets as the variable.

The results for the model of ATM use are quite interesting. Several variables lower the probability of the firm using 
an ATM:

- an IDR billion increase in assets lowers it by 5 percent (In January 2010, the exchange rate was USD = IDR 9,300.);

- older firms are less likely to use the ATM, but the effect is not very large - a 5 year increase in age lower the probability by 2.5 percent; and

- being in the education services industry lowers the likelihood by 27 percent, perhaps associated with the need of such organizations to control funds transfers rigorously.

On the other hand, having made a profit in the past year increases the likelihood of use by 14 percent; the result implies that the higher opportunity cost of visiting a branch the manager pushes him or her to use the ATM instead.

The model for the determinants of having a checking account is statistically strong. Factors significantly increasing the probability of having such an account are:

- having multiple accounts with a single bank raises the likelihood by 20 percent;

- firm age has a small but significant effect—an additional 10 years raises the likelihood by 4 percent; incremental assets have a similar effect -3 percent increase with a billion rupiah increase;

- being a limited liability company is associated with a 14 percent increase and being a proprietorship or partnership pushes up the probability by a large 40 percent, both for reasons not evident to the authors; and,

- size, as measured by employment, has a marginal effect— doubling the average firm size increases the probability by 2.5 percent.

Being located in Jakarta or a city of over 800,000 population lowers the probability of having such an account by 14 percent, suggesting that such accounts have been displaced in the bigger cities by other accounts and channels. Also, growing firms are 17 percent less likely to use such accounts.

The results for savings account are comparatively simple. The only push factor is a firm concentrating its financial accounts in one bank, which raises the probability by about 6 percent. On the other hand, greater assets, presumably implying greater size in this instance, lower the probability by 3 percent for each IDR billion.

Lastly, the model for use of bank transfer services is statistically strong and quite interesting. Firms in the accommodation, food and beverage sector are 27 percent less likely to use transfers, possibly to reduce the auditable record of its transactions. Other negative factors are: (a) being located in one of the biggest cities suggesting that some combination of savings and ATMs serve these firms' purposes better; and, (b) having had bank support for start-up, which reduces the probability of such an account by 23 percent; again other options are working better for them. Against all these negatives, being a limited liability corporation increases the likelihood of using transfers by a large 37 percent. The reason for this is unclear.

\section{Provider Choice}

Turning to the model for whether a firm chooses to take a loan from a commercial bank or another lender, one sees that service organizations are 27 percent less likely to select commercial banks. Firms with greater asset levels are also less likely to do so. It is hard to interpret this, since all lenders are asset-based. It is possible that firms with more assets have greater leverage in obtaining good terms with the regional development banks, cooperatives and other non commercial banks than they do with commercial banks.

On the other hand, those with outside start-up funding are almost 40 percent more likely to use commercial banks as their source, again suggesting relationship banking effects. Proprietorships and partnerships are also 23 percent more likely to turn to them. The reasons for the popularity of commercial banks to this group are not clear.

\section{Channel Choice}

One of the two channel choice models examines whether bank transfers are executed using a branch teller or any other method. The dependent variable indicates if some way other than the branch teller was employed. Two variables are highly significant and exert a positive influence on the choice to eschew banks. Firms turning a profit in the previous year are 12 percent more likely to use alternative channels, possibly because of their increasing opportunity cost in visiting a branch. The second variable indicates that the firm had outside start-up funds. This may reflect greater sophistication on the part of those who knew how to generate outside funds in the first place. Note that this is not necessarily inconsistent with relationship banking: the firm may still be using the same bank but through a different channel.

The second channel choice model is for accessing a savings account, either through an ATM (dependent variable $=1$ ) 
or by visiting the bank branch. Two highly significant factors steer firms to branches. Firstly, firms with more assets are about 10 percent more likely to visit the branch. It is possible that larger firms have sufficient staff that someone other than the owner-manager can handle this task so that the opportunity cost argument is weakened. Secondly, firms with the simplest form of registration are more likely to visit branch offices, implying a very limited degree of development. They are 3 percent more likely to visit a branch rather than use an ATM. After controlling for other factors, firms in Jakarta are 6 percent more likely to use an ATM, which may have to do with the greater availability of the machines and a higher sophistication level in using them.

\section{Conclusions}

The analysis identified distinct patterns in small and medium firms' choices of financial services from regulated sources. There are several overall patterns worthy of comment.

In no case was a significant difference in the pattern of female owner-managers from their male counterparts found, after controlling for other factors. Also, a firm belonging to a trade association had no significant effect.

Relationship banking appears to be a prominent financial market feature for small-medium firms. Getting bank support for start-up induces firms to take further loans; this is especially true when taking the loan from a bank, presumably the same bank. Additionally, having multiple accounts at a single bank has a significant positive effect on taking three products: loans, checking account, and savings account. More generally, the value of establishing a relationship with these firms through any product offers the opportunity for significant cross selling.

Growing firms, as measured by increased revenue in the last year, consistently select products and channels that would save time by reducing trips to the bank branch.

The firm's assets are often significant in these models. The reason for the direction of the effects is not always clear. Interestingly, after controlling for relationship banking factors, the asset level was not significant in the loan product selection model, despite the strong evidence of asset-based lending.

The service choice model results for ATMs and checking accounts are very interesting: three variables significant in both models have opposite signs in each indicating that the two products are substitutes. Younger firms, those with low assets and those with growth in the previous year (perhaps upstarts) prefer ATMs; ATMs are the choice of the future. This "start-ip" result is also supported by the channel choice model for savings accounts where the channels analyzed are use of the ATM or visiting the bank branch where firms with lower assets are more likely to be using ATMs.

These findings indicate that this type of analysis produces valuable results for banks and non bank financial institutions who wish to expand their business volume across an array of products. The results hold lessons for designing marketing campaigns and thinking about the relative emphasis in the future for expanding branches or ATMs and electronic banking. An important question is how stable the relationships identified here are in other Southeast Asian countries and beyond. One hopes to see similar studies completed in the near term.

\section{References}

Angur, M.G., R. Nataraajan, and J.S. Jahera, Jr. (1999). Service Quality in the Banking Industry: An Assessment in a Developing Economy, International Journal of Bank Marketing, vol.17, no.3, pp.116-23, doi:10.1108/02652329910269211, http://dx.doi.org/10.1108/02652329910269211

Asia Foundation. (2005), Indonesia Provincial SME Study. Jakarta: Report to the Asian Development Bank.

Ayyagari, M., Beck, T., and A. Demirguc-Kunt. (2007). Small and Medium Enterprises Across the Globe, Small Business Economics, vol.29, pp.415-34, doi:10.1007/s11187-006-9002-5, http://dx.doi.org/10.1007/s11187-006-9002-5

Bank Indonesia. (2005), Final Report on Research on the Profile of Indonesian Micro, Small and Medium Enterprises. Jakarta: Credit Department, Bank Indonesia.

Bebczuk, R.N. (2004). What Determines the Access to Credit by SMEs in Argentina. La Plata: Universidada Nacional de la Plata, Departmento de Economica, Documento de Trabajo nro. 48, processed.

Beck, T., and A. Demirguc-Kunt. (2006). Small and Medium-Size Enterprises: Access to Finance as a Growth Constraint, Journal of Banking \& Finance, vol.30, pp. 2931-43, doi:10.1016/j.jimonfin.2006.07.005, http://dx.doi.org/10.1016/j.jimonfin.2006.07.005

Beck, T., A. Demirguc-Kunt, L. Leven, and V. Maksimovic. (2006). The Determinants of Financing Obstacles, Journal of International Money and Finance, vol.25, pp. 932-52.

Beck, T., A. Demirguc-Kunt, and M.S. Martinez Perla. (2008). Bank Financing of SMEs around the World: Drivers, Obstacles, Business Models, and Lending Practices. Washington, DC: World Bank Policy Research Working Paper 
no. 4785 .

Casalo, L., C. Flavian, and M. Guinaliu. (2008). The Role of Usability and Satisfaction in the Consumer's Commitment to Financial Services Web Site, International Journal of Electronic Banking, vol.2, no12, pp.31-49.

Deputi Bidang Pengkajian Dan Sumberdaya UKM dan Koperasi. (2006). Hambatan Usaha Kecil Dan Menengah Dalam Kegiatan Ekspor, no. 1, tahun 1. pp. 99-112.

Development Alternatives, Inc. (DAI). (2004). Finance for Small and Medium Enterprise in Indonesia: Final Report. Bethesda, MD: Report to Japan Bank for International Cooperation.

Gao, P., and O. Owolabi. (2008). Consumer Adoption of Internet Banking in Nigeria, International Journal of Electronic Banking, vol.4, no.3, pp.284-99.

Gerrard, P., and J.B. Cunningham. (2003). The Diffusion of Internet Banking Among Singapore Consumers, International Journal of Bank Marketing, vol.21, no.1, pp.16-28, doi:10.1108/02652320310457776, http://dx.doi.org/10.1108/02652320310457776

Godau, M., W. Hiemann, and S. Jansen. (2004). SME Finance in Indonesia: Fact Finding Mission. Jakarta: Report to KfW-Jakarta Office.

Hwang, H.-G, H. R-F. Chen and J-M Lee. (2007). Measuring Consumer Satisfaction with Internet Banking, International Journal of Electronic Banking, vol.1, no.3, pp.321-35.

Ong, H.B., and Cheng, M.Y. (2003). Success Factors in e-channels: The Malaysian Banking Scenario, International Journal of Bank Marketing, vol.21, no.6/7, pp. 369-77, doi:02652320310498519, http://dx.doi.org/02652320310498519

Kaleem, A., and S. Ahmad. (2009). Determinants of SMEs' Perception of Electronic Banking in Pakistan, International Journal of Electronic Banking, vol.3, no.2, pp.133-48.

Patricio, L., R.P. Fisk, and J. Falacao e Cunha. (2003). Improving Satisfaction with Ban k Service: Measuring the Contribution of Each Delivery Channel, Managing Service Quality, vol. 13, no.6, pp.471-82, doi:10.1108/0960452310506531, http://dx.doi.org/10.1108/0960452310506531

Rafinaldy, N. (2004). Prospek Pengembangan Ekspor UKM, Majalah Infokop, vol. 25, no.20, pp. 99-106.

Schiffer, M., and B. Weder. (2001), "Firm Size and Business Environment: Worldwide Survey Results." Washington, DC: International Finance Corporation Discussion Paper 43.

Sijabat, Saudin. (2008). Potret Iklim Usaha Pemberdayaan UMKM, Majalah Infokop, vol.16, pp.1-17.

Soesilo, HM Iskandar. (2007). Strategi UMKM Dalam Mengatasi Sistem Dan Prosedur Kredit Komersial, Majalah Infokop, vol. 15, no. 2 pp. 1-17.

Struyk, R., K. Sarwoto M. Kwanisai, Y. Indra, and Sutrisna Ahbi. (2009). Serving Financial Needs of Indonesian SMEs: Project Surveys \& Methods. Bethesda, MD: NORC, Report to IFC-Indonesia, processed.

Struyk, R., S. Haddaway, and KC, S. (2010a). Serving the Financial Needs of Indonesians: Main Findings. Bethesda, MD: NORC Report to IFC-Jakarta, processed.

Struyk, R., S. Haddaway, and Y. Indra. (2010b). Serving the Financial Needs of Indonesians: Market Segment Results. Bethesda, MD: NORC Report to IFC-Jakarta, processed.

Subandi, Slamet. (2007). Potensi Pengembangan Permodalan, UMKM Dari Pinjaman Perbankan, Majalah Infokop, vol. 15 no.2, pp1-12.

Sulistyastuti, Dyah Ratih. (2004). Dinamika Usaha Kecil Dan Menengah (UKM):Analisis Konsentrasi Regional UKM di Indonesia 1999-2001, Jurnal Ekonomi Pembangunan, vol. 9, no. 2, Desember , pp. 143 - 164.

Susilo, Y. Sri, and Sutarta, A. Edi. (2004). Masalah Dan Dinamika Industri Kecil Pasca Krisis Ekonomi, Jurnal Ekonomi Pembangunan- Kajian Ekonomi Negara Berkembang, vol. 9, no. 1, pp. 79-90.

Syarif, Teuku. (2007). Proporsi Penyaluran Dana Perbankan Untuk UMKM, Majalah Infokop, vol. 15, no. 2, pp. $1-17$.

Notes

Note 1. Of course, a significant number of micro firms do grow to be small firms. A 2005 study of small and medium firms in East Java found that 53 percent of the firms then rated as small had started out as micro enterprises (DAI, 2005, p.64). 
Note 2. See Struyk et al., 2009 for a full description. The sample used the listing of all small-medium firms in these cities compiled by the national statistics agency (Badan Pusat Statistik-BPS) to create the sampling frame for the 2006 Economic Survey. The definitions of small and medium firms employed are BPS's.

Note 3. The specific question asked was, "How problematic is financing for the operation and growth of your business?" Answers vary between 1 (no obstacle) to 4 (major obstacle). Values are for about 2001 and may not be valid today. The article does not provide dates for all variables. By 2001 most of the changes in the banking system due to the Asian Crisis has been effected but further regulatory changes were likely ongoing (Sato, 2005).

Note 4 . For this model, we wanted to examine the choice of commercial banks versus coops, since 23 percent of loans were taken from coops in the weighted data. However, in the unweighted data only 8 of loans were originated by coops, so we were forced to change our dependent variable to represent commercial banks versus other sources.

Table 1. Use of Financial Services by Small and Medium Size Firms

\begin{tabular}{|c|c|c|c|c|c|c|c|}
\hline & & & \multicolumn{5}{|c|}{ Service/Product } \\
\hline & & & Savings/Deposit Account & $\begin{array}{l}\text { Checking } \\
\text { Account }\end{array}$ & $\begin{array}{l}\text { ATM } \\
\text { Card }\end{array}$ & $\begin{array}{c}\text { Business } \\
\text { Loan }\end{array}$ & $\begin{array}{c}\text { Send/Receive } \\
\text { Transfer }\end{array}$ \\
\hline \multicolumn{3}{|c|}{$\%$ of All Firms Using Service } & 88.3 & 13.4 & 59.6 & 12.8 & 28.1 \\
\hline \multicolumn{3}{|c|}{$\begin{array}{l}\% \text { of All Firms Using Formal Institutions } \\
\text { for Service }\end{array}$} & 88.2 & 13.3 & 59.4 & 11.0 & 27.8 \\
\hline \multirow{6}{*}{ 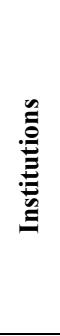 } & \multirow{6}{*}{ 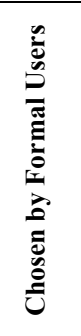 } & Cooperative & 0.1 & 0 & 0 & 23.1 & 0.8 \\
\hline & & Rural Bank & 1.4 & 0 & 2.0 & 0.5 & 0.1 \\
\hline & & Regional Development Bank & 0.9 & 1.1 & 0.7 & 0.8 & 0.3 \\
\hline & & Commercial Bank & 97.1 & 98.0 & 96.9 & 69.1 & 98.1 \\
\hline & & Sharia Bank & 0.4 & 0.8 & 0.3 & 6.2 & 0.6 \\
\hline & & Other & 0 & 0 & 0 & 0.3 & 0.1 \\
\hline \multirow{7}{*}{\multicolumn{2}{|c|}{ 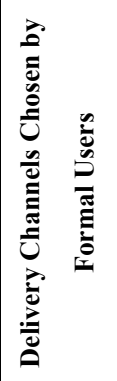 }} & Branches Teller & 91.2 & 95.1 & 0.8 & 94.7 & 73.7 \\
\hline & & Payment Card & 0 & 0.2 & 0.6 & 1.0 & 5.8 \\
\hline & & Internet Banking & 0.4 & 0.9 & 0 & 0.9 & 0.6 \\
\hline & & Phone Banking & 0.3 & 0 & 1.0 & 2.8 & 0.3 \\
\hline & & Call Center & 0.1 & 0 & 0.2 & 0 & 0.2 \\
\hline & & ATM & 8.0 & 3.3 & 96.4 & 0.6 & 19.5 \\
\hline & & Other & 0 & 0.4 & 1.0 & 0 & 0 \\
\hline
\end{tabular}

Table 2. Dependent Variables in Models Estimated

\begin{tabular}{|l|l|l|}
\hline \multicolumn{1}{|c|}{ Area } & \multicolumn{1}{|c|}{ Decision } & \multicolumn{1}{|c|}{ Dependent Variable Name } \\
\hline Service choice & Use ATM or not & ATM \\
\hline & Take out business loan & BLOAN \\
\hline & Have a checking account & CHECK \\
\hline & Have a savings account & SAVE \\
\hline & Use a provider for cash transfers & TRANSFER \\
\hline Provider choice & Take loan from cooperative vs a commercial bank ${ }^{\mathrm{a}}$ & LOAN-COOP \\
\hline Channel choice & Access savings accounts through $\mathrm{ATMs}^{\mathrm{b}}$ & SAVE-ATM \\
\hline & Transfer is through ATM vs bank branch $^{\mathrm{c}}$ & TRANS-ATM \\
\hline
\end{tabular}

a. Population is firms that took loan from one of these two sources. Variable is 1 if loan is from a coop.

b. Population is firms with savings accounts who access them through either branch offices or ATMS. Variable is 1 if access is through an ATM.

c. Population is firms who have taken loans through branch offices or telephone access. Variable is 1 if transfer was by ATM. 
Table 3. Summary of Hypotheses and Corresponding Variable Definitions

\begin{tabular}{|c|c|c|c|}
\hline Hypotheses & Variables Created & Short name & Mean \\
\hline $\begin{array}{l}\text { Size. Other things equal, larger firms get more respect and attention at } \\
\text { financial institutions, increasing the likelihood that they will use } \\
\text { services. They are also more sophisticated and should be more open to } \\
\text { new services and delivery channels. On the other hand, they may use } \\
\text { different services than smaller firms, e.g., more use of payroll services } \\
\text { and less of ATMs. }\end{array}$ & $\begin{array}{l}\text { Number of employees, approximated using the } \\
\text { midpoint of a reported range }\end{array}$ & EMP & 25.07 \\
\hline $\begin{array}{l}\text { Possible discrimination against women at branch offices causes them } \\
\text { not to apply for services. This could also cause them to give preference } \\
\text { to ATM or phone services. }\end{array}$ & $\mathrm{VAR}=1$, if owner/manager is female & FEML & 0.39 \\
\hline \multirow{3}{*}{$\begin{array}{l}\text { Better educated owner/managers are more likely to understand } \\
\text { financial products and use them, search for alternative providers, and } \\
\text { use new delivery channels }\end{array}$} & $\mathrm{VAR}=1$, if senior high school completed & ED1 & 0.26 \\
\hline & $\mathrm{VAR}=1$, if university-no diploma & ED2 & 0.06 \\
\hline & $\mathrm{VAR}=1$, if university completed & ED3 & 0.54 \\
\hline $\begin{array}{l}\text { Older firms have had a longer time to build their reputations which } \\
\text { improves access to services; but older firms may be slower to shift to } \\
\text { new delivery channels after building access through bank branch }\end{array}$ & Age of firm in years & AGE & 16.47 \\
\hline \multirow{4}{*}{$\begin{array}{l}\text { Legal forms that make it relatively more difficult for a lender to attach } \\
\text { personal assets as well as company assets in case of loan default. } \\
\text { Limited liability often signals a larger and more sophisticated firm. } \\
\text { Effects on other service choices and delivery channel choices are } \\
\text { expected to be small. }\end{array}$} & VAR $=1$, if firm is a limited liability corporation & LEG1 & 0.25 \\
\hline & $\mathrm{VAR}=1$, if firm is a proprietorship or partnership & LEG2 & 0.01 \\
\hline & $\mathrm{VAR}=1$, if firm is a limited partnership & LEG3 & 0.10 \\
\hline & $\mathrm{VAR}=1$, if firm has a limited registration ${ }^{\mathrm{c}}$ & LEG4 & 0.33 \\
\hline $\begin{array}{l}\text { Lenders are primarily doing asset-based lending; so well-endowed } \\
\text { firms are more likely to borrow. Variables may also be another } \\
\text { measure of "size;" see hypotheses above. }\end{array}$ & $\begin{array}{l}\text { Value of assets (in billion IDR), approximated using the } \\
\text { midpoint of a reported range }\end{array}$ & ASSETS & 0.99 \\
\hline $\begin{array}{l}\text { Use of formal finance for start-up expenses signifies unusual } \\
\text { knowledge of such transactions and a positive external assessment of } \\
\text { the business. Firms more likely to try new service providers and } \\
\text { delivery channels }\end{array}$ & $\begin{array}{l}\mathrm{VAR}=1, \text { if firm took loan from cooperative, commercia } \\
\text { bank or supplier to partially finance start-up }\end{array}$ & ISTARTFND & 0.17 \\
\hline $\begin{array}{l}\text { Business association members are more progressive, interested in } \\
\text { picking up good practices and networking. More likely to access a } \\
\text { wider range of financial services and to use wider range of delivery } \\
\text { channels. On the other hand, may be likely to stay with established } \\
\text { services }\end{array}$ & $\mathrm{VAR}=1$, firm is member of business association & ASSOC & 0.31 \\
\hline $\begin{array}{l}\text { Positive business results gives basis for expansion and improvements } \\
\text { in operations increasing demand for financial services generally, effect } \\
\text { maybe more in volume of services already used rather than new } \\
\text { services. Not expected to influence choice of delivery channels. }\end{array}$ & VAR $=1$, if had revenue increase in 2008 & REV08 & 0.49 \\
\hline Business practices are more advanced in the largest cities and financial & $\mathrm{VAR}=1$, if Jakarta & BIG1 & 0.25 \\
\hline \multirow{2}{*}{$\begin{array}{l}\text { services are more readily available, both factors working to increase } \\
\text { use of financial services. Larger cities may also have better ATM } \\
\text { coverage favoring this channel. }{ }^{\text {b }}\end{array}$} & $\begin{array}{l}\text { VAR }=1 \text {, if in any of three other very large cities: } \\
\text { Bekasi, Surabaya, Tangerang }\end{array}$ & BIG2 & 0.20 \\
\hline & $\mathrm{VAR}=1$, if city is Jakarta or other big 3, i.e. any big city & BIG3 & 0.45 \\
\hline $\begin{array}{l}\text { Greater concentration of accounts with a single financial institution } \\
\text { signals a stronger relationship with the bank likely facilitating } \\
\text { accessing service: "relationship banking." More services used due to } \\
\text { cross selling. Because commercial banks offer wider variety of } \\
\text { services, opportunities for cross selling are greater for them. So } \\
\text { commercial banks favored provider. Delivery channeled favored may } \\
\text { be branches, where "relationship" can be continued. }\end{array}$ & $\begin{array}{l}\text { Maximum number of accounts with any single financia } \\
\text { institution }\end{array}$ & $1 \mathrm{BNKCONC}$ & 1.55 \\
\hline \multirow{5}{*}{$\begin{array}{l}\text { Different industries have different needs for financial services and } \\
\text { working capital and investment funds. Essentially a control variable. }\end{array}$} & \multicolumn{3}{|c|}{$\begin{array}{l}\text { A separate dummy variable defined for each industry that accounts for at } \\
\text { least } 10 \% \text { of firms included in the sample: }\end{array}$} \\
\hline & Wholesale and retail trade & IND2 & 0.18 \\
\hline & Accommodation and food and beverage & IND3 & 0.10 \\
\hline & Public service, social, and personal services & IND6 & 0.13 \\
\hline & Education services & IND9 & 0.12 \\
\hline
\end{tabular}

a. These are small firms that are registered as existing but have very limited operational rights; typically they are traders. To obtain a license for additional activities, they have to re-register in one of the other categories. Excluded categories are: government company, cooperative, representative office of foreign firm, firm operating under a special permit. The omitted types each accounts for a very small share of firms.

b. The city population categories were: DKI Jakarta, 7.5 million; next large category, 2.7 million to 800,000 . Two further groups were defined but one $(800,000$ to 425,000$)$ was consistently significant and places smaller than this, but of at least 250,000 population, served as the omitted dummy variable. 
Table 4. Logit Model Results (Cell entries are the effect on the probability of making the choice)

\begin{tabular}{|c|c|c|c|c|c|c|c|c|}
\hline \multirow[b]{2}{*}{ Independent variables } & \multicolumn{5}{|c|}{ Service Choice } & \multirow{2}{*}{\begin{tabular}{|c|} 
Loan source \\
NONCOMM \\
BANK \\
\end{tabular}} & \multicolumn{2}{|c|}{ Delivery channel } \\
\hline & ATM & LOAN & CHECKING & SAVING & TRANSFER & & \begin{tabular}{|c} 
TRANS NON \\
BANK \\
\end{tabular} & SAVE-ATM \\
\hline Constant & $.069^{* *}$ & $-.409 * *$ & $-.720 * *$ & $.281 * *$ & $.389 * *$ & -.080 & $-.251 * *$ & $-.083 * *$ \\
\hline ASSETS & $-.054 * *$ & & $.030^{*}$ & $-.029 *$ & & $.043 * *$ & & $-.095 * *$ \\
\hline REV08 & $.140 * *$ & & $-.117 * *$ & & & & $.122 * *$ & \\
\hline AGE & $-.005^{* *}$ & .001 & $.004 * *$ & -.001 & & & & \\
\hline IND3 & & & & & $-.268 * *$ & & & \\
\hline IND6 & $-.163 * *$ & & & & & $.268 * *$ & & \\
\hline IND9 & $-.274 * *$ & & & & & & $.297 * *$ & \\
\hline FEML & -.060 & -.018 & .038 & & & & & \\
\hline STARTFND & & $.165 * *$ & & & $-.231 * *$ & $-.386 * *$ & $.152 * *$ & \\
\hline BNKCONC & & $.090 * *$ & $.203 * *$ & $.056 * *$ & & & -.024 & \\
\hline EMP & & & $.001 *$ & & $.002 * *$ & & .001 & \\
\hline BIG1 & & & & -.115 & & & & $.061 * *$ \\
\hline BIG2 & & & & .117 & & & & .040 \\
\hline BIG3 & & & $-.136 * *$ & & $-.228 * *$ & & & \\
\hline LEG1 & & & $.136 * *$ & & $.374 * *$ & & & -.089 \\
\hline LEG2 & & & $.404 * *$ & & & $-.226 * *$ & & .688 \\
\hline LEG3 & & & & & & & & -.057 \\
\hline LEG4 & & & & & & & .060 & $-.030 * *$ \\
\hline ASSOC & & & .041 & & & & & \\
\hline $\begin{array}{l}\text { Mean, dependent } \\
\text { variable }\end{array}$ & 0.48 & 0.20 & 0.37 & 0.86 & 0.41 & 0.22 & 0.20 & 0.04 \\
\hline-2 log likelihood & 721 & 525 & 567 & 373 & 679 & 149 & 223 & 131 \\
\hline Cox \& Snell R2 & .131 & .083 & .274 & .058 & .168 & .198 & .052 & .071 \\
\hline Nagelkerke R2 & .175 & .130 & .373 & .115 & .227 & .301 & .083 & .244 \\
\hline
\end{tabular}

*Variable significant at the .10 level or higher**Variable significant at the .05 level or higher 